the first nuclear bomb was construeted. Allison served in this project from its beginning until 1944. He served as director of the Laboratory during the final year of this period. He jested that his main job was to sign the huge stacks of blueprints and documents having to do with the construction of the great nuclear reactors at Hanford.

In November 1944, he went to the Los Alamos Laboratory to work more directly on the development of the atomic bomb. He served as ehairman of the Technical and Scheduling Committee which scheduled the final stages of the test of the first atomic bomb on July 16, 1945. He made history when his voice sounded across the New Mexico desert, counting off seconds to zero on that memorable dawn that witnessed the first nuclear explosion.

September 1, 1945, was the day on which the University of Chicago announced the formation of its new research institutes with Allison as the newly appointed director of the Institute for Nuclear Studies. Such luminaries as Enrico Fermi and Harold. Urey were already enlisted as members. It was on this occasion that Allison made what came to be known as "Sam's butterfly speech". He warned that if the exchange of scientific information was prohibited by military regulation, scientists in America would leave the field of atomic energy and devote themselves to such subjects as the colours of butterfly wings. The speech became the opening salvo in the campaign the scientists fought to prevent military control of the peacetime development of atomic energy.

He served as the first director of the Institute of Nuclear Studies (later renamed for Enrico Fermi) until his death, except for one five-year interlude. The Institute was devoted to the idea that physicists, chemists, and astrophysicists had complementary interests and could work together under one roof with mutual benefit. Under Allison's stewardship the Institute flourished. The seminars were brightened by such men as Fermi, Teller, Urey, J. Meyer, Wentzel, Chandrasekhar, Gell-Mann, and Dalitz. Many new ideas were developed, among them two that have already won Nobel prizes: radio carbon dating (W. F. Libby) and the nuclear shell model (M. G. Mayer).

Allison was awarded the Medal of Merit for his work on the atomic bomb: he was a founding member of the Board of Sponsors of the Bulletin of the Atomic Scientists. He was elected a member of the National Academy of Sciences in 1946 and served as chairman of its Physical Section from 1960 until 1963. He served as guest lecturer and adviser in nuclear physies matters on several occasions in Spain, in Argentina, and in the United Arab Republic.

Allison was a large man and his tall stature and silverywhite hair gave him a striking presence in any gathering among men. It was difficult to disturb his sense of equilibrium and he had an air of imperturbable calm that made doubly effective the sound common sense he could interpose at the propitious moment in colourful but clear and quotable language. He never failed to find a humorous side to every situation, however tense.

He enjoyed the life of teaching and research. He never lost an opportunity to work in the laboratory with his own hands. He had a natural talent and the requisite patience for making his apparatus work and he took a particular pride in displaying these skills to his students.

$\mathrm{He}$ was a man who asked little but gave much. His friends, colleagues and former students mourn their loss.

H. L. ANDERSON

\section{Dr. H. R. Lang}

Dr. Herbert Raphael Lang, who died suddenly on November 18 at the age of sixty-one, had been secretary of the Institute of Physics, and afterwards of the amalgamated body of the Institute of Physies and the Physical Society, since 1932. His connexion with the Institute went even further back than this and he was present as a schoolboy at the inaugural meeting in 1921. Lang read physics at the Imperial College of Science and Technology, and after his first degree continued as research student and demonstrator, gaining his Ph.D. for work on the investigation of the effect of temperature on the specific heats of liquids. His work on the thermal properties of liquids continued after his appointment to a research Fellowship by the Institute of Petroleum. He could have made an outstanding career in research or in industry but, fortunately for the physics profession, he was persuaded to become secretary of the Institute. It is difficult to imagine anyone better suited for such a post. Apart from his deep interest in physics he had a rare combination of wisdom, realism, determination and loyalty, as well as an enormous capacity for hard work, and above all a kindly and unselfish nature. No task associated with physics was too great or too small for him, whether it was organizing an international conference, forming a new subject group, giving professional advice to a junior colleague or operating the benevolent fund.

Lang was, by nature, shy and retiring. Although most members of the Institute and Society realized that he played a very large part in its affairs, it was only those who were privileged to work closely with him who fully appreciated the extent of his efforts and devotion. His work was conducted largely behind the scenes and he sought no personal credit. New developments and policies which were largely inspired by him were usually presented to the members through the honorary officers. At the same time, he was always ready to give credit to his own staff.

When Lang took office in 1932 the physics profession, as such, barely existed. To-day there are more than eleven thousand members, drawn from academic establishments, industry and government service. Under Lang's guidance, this vast number of pure and applied physicists, distributed throughout the United Kingdom and abroad, have developed, through the branches and specialist groups, common interests and activities, and a sense of belonging to the profession. From his early days in the Institute of Physics, Lang maintained close contact with the Physical Society, and it was due in no small measure to his untiring efforts during many years that amalgamation of the two bodies was effected in 1960 .

Physics owes much to Lang and he will be greatly missed. He leaves a widow and three sons.

\section{R. Gavin}

\section{W. B. Alexander}

W. B. Alexander, formerly director of the Edward Grey Institute of Field Ornithology, University of Oxford, died on December 18, 1965, at the age of eighty. He was educated at Bootham School, York, Tonbridge School, and King's College, Cambridge. The Cambridge degree ceremony then involved a procession, headed by the first-class honours men (in alphabetical order) from the college providing the Vice-Chancellor, and in 1909 it was led by W. B. Alexander and the man he referred to as 'young Brooke'. After brief appointments in the Cam. bridge Museum of Zoology and then as assistant naturalist to the Board of Fisheries (North Sea), he accepted, in 1912, the post of assistant in the Western Australian Museum, Perth, and was Keeper of the Biological Department there from 1914 to 1919 (apart from two years in Melbourne on war work as a science abstracter). In this period he revitalized the Perth museum. After a brief return to England, he was biologist to the Prickly Pear Board from 1920 until 1925, and thus a prominent member of the team which effected one of the most successful examples of biological control of a pest ever recorded. Alexander being the man who first brought live Cactoblastis from South America to Australia. While in Australia he also played a prominent part in the Royal 
Society of Western Australia and the Royal Australian O.nithologists' Union, and he is warmly remembered by Australian ornithologists.

On his voyages to England in 1920 and 1926, he was struck by the difficulty of identifying sea-birds, and this resulted in his best-known work, The Birds of the Ocean, published in 1928, which may fairly claim to be the first ornithological field guide. Aftor 3 years without a regular post (he was a bachelor with modest private moans), he was in 1929 appointed superintendent of the Teos survey of the Marine Biological Association. He left this post in October 1930 to become director of the Oxford Bird Census, founded by E. M. Nicholson, the late B. W. Tucker and the Oxford Ornithological Society, which, after the creation of the British Trust for Ornithology in 1933-34, became the Institute of Field Ornithology, and in 1938 the Edward Grey Institute. In his poriod as diroctor, he played a valuable part in encouraging undergraduate ornithologists, and it was after taking undergraduato parties to trap migrants on Holy Island in 1931 and 1932 , and a visit with senior ornithologists to Heligoland in 1933, that Alexander stimulated the founding of the first British Bird Observatories, on Skokholm and the Isle of May. His other main service was to build up the library of the Edward Grey Institute, much of it from his own pocket, as funds were very low. When he retired as director in 1945, he remained as librarian for a further ten years, and the library was named after him. His remarkable memory, usually precise to the part of a page, helped all in search of information. By now, the Alexander Library is probably the most complete ornithological library in the world, and the residue of Alexander's estate has been bequeathed to it.

D. LACK

\section{NEWS and VIEWS}

\section{The Academy of Sciences of the U.S.S.R.: Foreign Members}

ThIRTY-FIVE scientists were elected Foreign Members of the Academy of Sciences of the U.S.S.R. at the recent meeting in Moscow. Included among these were four British scientists: Lord Florey, past-president of the Royal Society, and Provost of The Queen's College, University of Oxford; Prof. P. M. S. Blackett, president of the Royal Society and emeritus professor of physics, University of London, and part-time scientific adviser to the Ministry of Technology; Sir Robert Robinson, pastpresident of the Royal Society and emeritus professor of chemistry, University of Oxford: and Sir Geoffrey Taylor, formerly Yarrow rescarch professor of the Royal Society. The total number of Foreign Members of the Academy of Sciences of the U.S.S.R. is now seventy-three.

\section{Honorary Fellowship of the Institute of Mathematics and its Applications : Sir Geoffrey Taylor, F.R.S.}

THE Institute of Mathematics and its Applications has elected Sir Geoffrey Taylor as its first Honorary Fellow. Sir Geoffrey, who will celebrate his eightieth birthday on March 7, 1966, has made distinguished mathematical and experimental contributions to the mechanics of fluids and solids and their technological and geophysical applications. He was elected to Fellowship of the Royal Society in 1919 and received the Copley Medal in 1944. From 1923 until 1952 he was a Yarrow research professor of the Royal Society. Sir Geoffrey Taylor has been honoured by universities, academies and societies throughout the world. A formal presentation of the certificate of honorary fellowship will be made at the Tmperial College of Science and Technology, London, in the Department of Physics on February 23, immediately preceding a lecture to the Institute by Dr. J. W. S. Cassels on "What are $p$-Adic Numbers?"

\section{The Scottish Horticultural Research Institute, Mylnefield, Invergowrie: Dr. T. Swarbrick, C.B.E.}

DR. T. SWARBRICK retired from the post of director of the Scottish Horticultural Research Institute, Mylnefield, Invergowrie, on January 31,1965 . He was appointed as the first director of the Institute on its establishment in 1951 and his retirement after 14 vears thus marked the end of the first phase in the development of this important centre of horticultural research in Scotland. Dr. Swarbrick received his scientific training at the University of Leeds, where he graduated in agriculture and botany (1923), B.Sc. Hons. in botany (1924) and Ph.D. in plant physiology
(1927), after holding a Ministry of Agriculture scholarship at Leeds, Long Ashton and Wisconsin (U.S.A.). On completing his training, he served on the staff of the Long Ashton Research Station first as physiologist and later as pomologist until 1945, when he joined the scientific staff of the Royal Dutch Shell Group, with headquarters in The Hague and Amsterdam. This was followed in 1951 by his appointment at Mylnefield, whore he had the task of establishing and developing this new research centre to serve the special needs of the Scottish horticultural industry. In developing the research programme there, Dr. Swarbrick used as a basis the research units of the Department of Agriculture for Scotland for the investigation of diseases of raspberries and strawberries at Dundee and Auchincruive, and these subjects are still prominent in the present programme. Other important subjects of investigation include the breeding of raspberries, strawberries and vegetables, and the occurrence of natural growth substances in the strawberry in relation to environmental factors and developmental effects. Mylnefield, under Dr. Swarbrick's able guidance, has become a national research centre of repute and is a fitting memorial to his scientific ability and vision, his drive and enthusiasm, and his high personal qualities. His distinguished work there was officially recognized by the award of a C.B.E. in 1964; he has received the 1965 Scottish Horticultural Medal.

\section{Organization for Economic Co-operation and Develop- ment}

THE Organization for Economic Co-operation and Development (O.E.C.D.), successor to the Organization for European Economic Co-operation (O.E.E.C.), was established in 1961 ; it comprises all the industrialized countries of North America and Western Europe, and also Japan. Three major aims guide its policy: first, promotion of the highest sustainable economic growth and employment and a rising standard of living in the member countries; secondly, support for sound economic expansion of member and non-member nations in the process of development; and thirdly, furtherance of the expansion of world trade on a multilateral, non-diseriminatory basis. This Organization functions primarily as a forum for policy-making representatives of member Governments, and a brief account of its work has previously been noted in these columns (Nature, 205, 1098; 1965). To take one example, agriculture, ". . . Because of the difficulties encountered in adapting national agricultural policies to the requirements of fuller co-operation, agriculture has often been considered an obstacle to co-operation. So far 